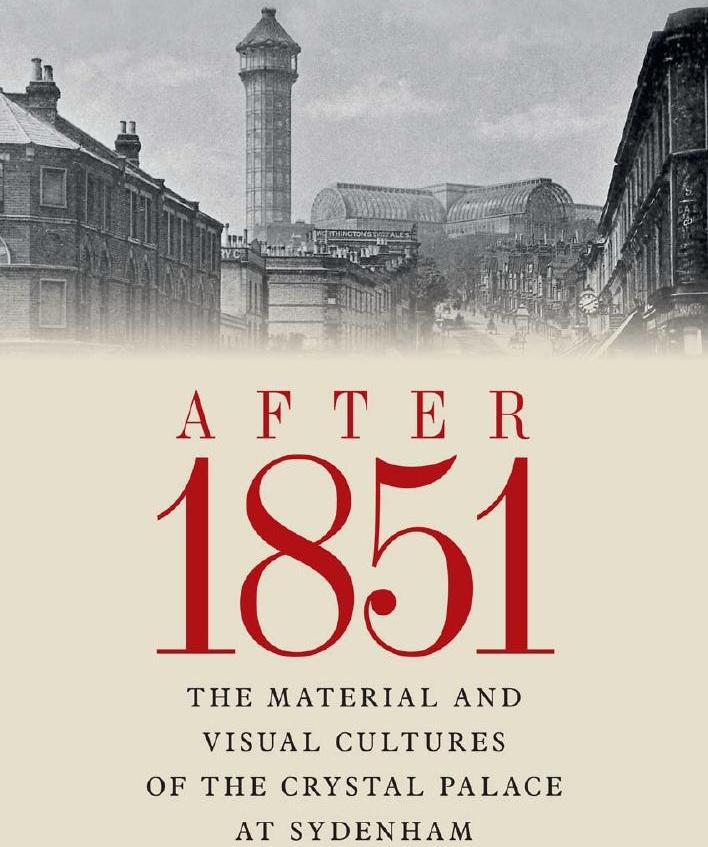

Nichols and Sarah Victoria Turner - 9781526114938

KA'T E ' NICHOL S ${ }^{23}$ A N D SARAH VICTORIA T URNER 


\section{After $185^{\mathrm{I}}$}

\section{MANCHESTER 1824}

Manchester University Press 
Kate Nichols and Sarah Victoria Turner - 9781526114938 Downloaded from manchesterhive.com at 04/26/2023 11:59:18AM 


\section{After I85I \\ The material and visual cultures of the \\ Crystal Palace at Sydenham}

Edited by Kate Nichols and
Sarah Victoria Turner

Manchester University Press 
Copyright (C) Manchester University Press 2017

While copyright in the volume as a whole is vested in Manchester University Press, copyright in individual chapters belongs to their respective authors, and no chapter may be reproduced wholly or in part without the express permission in writing of both author and publisher.

Published by Manchester University Press

Altrincham Street, Manchester Mi 7JA

www.manchesteruniversitypress.co.uk

British Library Cataloguing-in-Publication Data

A catalogue record for this book is available from the British Library

Library of Congress Cataloging-in-Publication Data applied for

ISBN 978 o719 096495 hardback

First published 2017

The publisher has no responsibility for the persistence or accuracy of URLs for any external or third-party internet websites referred to in this book, and does not guarantee that any content on such websites is, or will remain, accurate or appropriate.

Typeset in Monotype Baskerville by

Servis Filmsetting Ltd, Stockport, Cheshire 